GLOBAL BIOGEOCHEMICAL CYCLES, VOL. 1, NO. 4, PAGES 345-355, DECEMBER 1987

\section{THE DISTRIBUTION OF NITROGEN OXIDES OFF THE EAST COAST OF NORTH AMERICA}

Bryan A. Misanchuk, Donald R. Hastie and Harold I. Schiff

Chemistry Department and Centre for Atmospheric Chemistry, York University, North York, Ontario, Canada

\begin{abstract}
Measurements of $\mathrm{NO}$ and $\mathrm{NO}_{x}^{\prime}$ (as measured by a chemiluminescent analyzer equipped with a $\mathrm{FeSO}_{4}$ converter) were made from an aircraft off the east coast of North America in January and February 1986. These measurements show the mixing ratios of the nitrogen oxides to be higher than encountered in remote continental or marine environments. Both the free troposphere and boundary layer mixing ratio distributions are skewed toward high mixing ratios and are best described by a gamma probability distribution. The mean mixing ratios observed were 2.9 parts per billion by volume (ppbv) in the boundary layer and $0.55 \mathrm{ppbv}$ in the free troposphere for $\mathrm{NO}_{x}^{\prime}$ and $0.56 \mathrm{ppbv}$ in the boundary layer and 0.18 in the free troposphere for NO.
\end{abstract}

\section{INTRODUCTION}

The odd nitrogen compounds (compounds containing nitrogen but excluding $\mathrm{N}_{2} \mathrm{O}$ and $\mathrm{N}_{2}$ ) play two important roles in the atmosphere. They are responsible for the level of oxidants, and contribute to the atmospheric acidity. Nitrogen dioxide photolysis is an essential step in the formation of tropospheric ozone since it is the only process, other than ozone photolysis, which can yield an oxygen atom. Ozone photolysis can produce excited oxygen atoms which, on reaction with water and hydrocarbons, produce hydroxyl radicals, the major initiator of tropospheric oxidation processes. Oxidants such as $\mathrm{HO}_{2}, \mathrm{RO}_{2}$ and $\mathrm{H}_{2} \mathrm{O}_{2}$ all owe their existence to hydroxyl radicals and so they,

\section{Copyright 1988 \\ by the American Geophysical Union.}

Paper number $8 \mathrm{~J} 0060$.

0886-6236/88/008J-0060\$10.00 too, originate ultimately from nitrogen dioxide. Nitrogen dioxide also reacts with the hydroxyl radical to produce nitric acid. This is thought to be the most important reaction controlling the radical concentration. In addition, the nitric acid produced can be a sizable contributor to acid precipitation [National Academy of Sciences (NAS), 1984].

Odd nitrogen mixing ratios in clean air are very low. Hoell et al. [1987], Davis et al. [1987] and Ridley et al. [1987] report marine boundary layer NO values as low as 1 part per trillion by volume (pptv), and free troposphere values generally below $10 \mathrm{pptr}$ off the coasts of California and Hawaii. In the same area Carroll and Ridley (1984) report $\mathrm{NO}_{x}\left(\mathrm{NO}+\mathrm{NO}_{2}\right)$ mixing ratios of less than 100 pptv for altitudes up to $20,000 \mathrm{ft}$. $(7,000 \mathrm{~m})$. McFarland et al. [1979] found maximum NO mixing ratios of $4 \mathrm{pptv}$ at the surface of the equatorial Pacific Ocean. In cases where air was clearly coming off the ocean, Torres [1985], and Carroll et al. [1985] report ground level NO mixing ratios at Wallops Island, Virginia of 30 to 70 pptv. The extensive data sets from Niwot Ridge, Colorado show, in cases not severely influenced by pollution from the Denver area, continental $\mathrm{NO}_{x}$ mixing ratios averaging 500 pptv [Fahey et al., 1986; Bollinger et aI., 1984; Fehsenfeld et al., 1983; Parrish et al., 1986]. Kley et al. [1981] measured $\mathrm{NO}_{x}$ over Wheatland, Wyoming and found a decreasing mixing ratio with height ranging from $700 \mathrm{pptv}$ at $1.8 \mathrm{~km}$ above mean sea level (msl) $(0.4 \mathrm{~km}$ above ground) to 100 pptr at $7 \mathrm{~km}$ above msl with a scale height of $2 \mathrm{~km}$ at the lower altitudes.

Over eastern North America anthropogenic odd nitrogen emissions are larger than natural emissions and, because of their importance in local and regional pollution, are reasonably well quantified. Logan [1983] has estimated anthropogenic and natural emissions of odd nitrogen (emitted as NO) over this area to be about 3.8 and $0.7 \mathrm{Tg} \mathrm{N} / \mathrm{yr}$ respectively. 
Previous measurements at or off the east coast of North America have shown odd nitrogen mixing ratios well above those in more remote areas. Galloway et al. [1984] summarized the eastern North American network odd nitrogen data bases (we note that, although these measurements have previously been identified as $\mathrm{NO}_{x}$, the instruments measure close to the total odd nitrogen, so we have called these measurements simply, odd nitrogen). The SURE (Sulphate Regional Experiment) data set [Mueller and Hidy, 1983] gives average odd nitrogen values of 6.0 and 2.4 parts per billion by volume (ppbv) for the boundary layer and free troposphere respectively, although the free troposphere values are acknowledged to be high due to the relatively high detection limit of the analyzer. The NASN (National Air Surveillance Network) data base gives surface odd nitrogen mixing ratios of 14.6 to $32.7 \mathrm{ppbv}$ but this data base is heavily weighted toward urban centers and is not typical of the area. The Canadian surface networks show much lower values of 0.32 to $4.8 \mathrm{ppbv}$ reflecting the more remote location of the samplers and the lower odd nitrogen emissions in this area. Wolff et al. $[1986 \mathrm{a}, \mathrm{b}]$ report average, ground-based odd nitrogen values of $5 \mathrm{ppbv}$ in the summer and $11 \mathrm{ppbv}$ in the winter at Lewes, Delaware, and $\mathrm{NO}_{2}$ values of $0.57 \mathrm{ppbv}$ in the summer and 0.76 in the winter at Bermuda, about $1,000 \mathrm{~km}$ from the North American east coast. Hastie et al. [1988] report winter $\mathrm{NO}$ and $\mathrm{NO}_{x}^{\prime}$ (odd nitrogen as measured by a chemiluminescent analyzer with a $\mathrm{FeSO}_{4}$ converter) average mixing ratios at Lewes, Delaware of 1.8 and $7.1 \mathrm{ppbv}$ respectively. From aircraft flights over the Atlantic Ocean, but within $50 \mathrm{~km}$ of the Virginia coast, Hastie et al. [1988] report boundary layer and free troposphere NO mixing ratios of 3.3 and $0.2 \mathrm{ppbv}$ respectively, and $\mathrm{NO}_{x}^{\prime}$ values of $12.3 \mathrm{ppbv}$ in the boundary layer and 1.0 in the free troposphere. Luke and Dickerson [this issue] report average boundary layer and free troposphere $\mathrm{NO}_{x}^{\prime}$ mixing ratios of 1.24 and 0.24 ppbv respectively, from aircraft flights averaging $300 \mathrm{~km}$ off the east coast of North America. On a flight from Halifax to Bermuda, J. W. Drummond et al. (Measurements of nitric oxide between $0-12 \mathrm{~km}$ altitude and $67^{\circ} \mathrm{N}-60^{\circ} \mathrm{S}$ latitude obtained during STRATOZ III, submitted to Journal for Geophysical Research, 1987) measured NO mixing ratios of 0.02 to $0.04 \mathrm{ppbv}$ below 8 $\mathrm{km}$, and an average of $0.15 \mathrm{ppbv}$ at $10 \mathrm{~km}$. Carroll et al. [1985] and Torres [1985] report surface NO mixing ratios of 0.2 to $0.3 \mathrm{ppbv}$ at Wallops Island, Virginia for times when the air was clearly coming from the continent.

Clearly the east coast odd nitrogen mixing ratios are higher than those in remote areas and this additional nitrogen is going to greatly perturb the regional nitrogen cycle. The same is true for sulphur and a number of other atmospheric components. The Western Atlantic Ocean Experiment (WATOX) was initiated to examine the influence of this material on eastern North America and the western Atlantic Ocean by determining the amount of nitrogen, sulphur, trace metals, and organics that are advected eastward from North America over the ocean. A second aim was to determine the fate of this material after it left North America.

Using several years of meteorological records, Whelpdale et al. [1984] determined the average mass of air cross- ing the eastern North American coastline as functions of latitude and altitude. Including the mixing ratio of a trace species, again as a function of latitude and altitude, into this calculation allows the flux of the trace species to be determined. Galloway et al. [1984] used the available mixing ratio data of the time [mainly the SURE data] to determine advection fluxes for sulphur and nitrogen as a function of latitude and altitude. For both species they found a broad maximum in transport between $38^{\circ} \mathrm{N}$ and $52^{\circ} \mathrm{N}$ with between $22 \%$ and $69 \%$ of the emitted odd nitrogen advected eastward. This large range in the calculated flux was due to limited data on the odd nitrogen mixing ratios, particularly as a function of altitude.

In 1985 WATOX entered a measurement phase to improve the data base for these flux calculations and to determine the fate of nitrogen, sulphur, organic and metal compounds once they leave the continent. An overview of the WATOX-85 measurement program is given by Galloway et al. [1988]. This campaign produced only limited nitrogen measurements off the east coast [Hastie et al., 1985]. The present paper describes our involvement in WATOX-86 A and $B$ where we measured $N O$ and $\mathrm{NO}_{x}^{\prime}$ during a total of 21 flights off the North American east coast, in the vicinity of Boston.

\section{INSTRUMENT AND SAMPLING SYSTEM}

Measurements were made from the National Oceanic and Atmospheric Administration (NOAA) Air Quality Division's King Air C-90 Aircraft. This aircraft has a payload capacity of $1,620 \mathrm{~kg}$ including fuel, a cruising speed of 113 $\mathrm{ms}^{-1}$, although this was lowered to $55 \mathrm{~ms}^{-1}$ for filter sampling in this program, and a flight duration of 5 hours. The aircraft was equipped with real-time instruments to measure $\mathrm{SO}_{2}, \mathrm{O}_{3}, \mathrm{NO} / \mathrm{NO}_{x}^{\prime}$, dew point and temperature. Several filter pack, cartridge and grab sample systems were available as were an FSSP (Forward Scattering Spectrometer Probe) and an ASASP (Active Scattering Aerosol Spectrometer Probe), for aerosol measurements. The aircraft was operated unpressurized and forced air entered a sampling manifold through a forward pointing stainless steel inlet on the top of the aircraft.

The $\mathrm{NO} / \mathrm{NO}_{x}^{\prime}$ instrument was a York-Scintrex chemiluminescent analyzer based on the reaction of $\mathrm{NO}$ with $\mathrm{O}_{3}$ and is shown schematically in Figure 1. Air was drawn from the sampling manifold through the instrument by a Leybold Heraeus model D4A rotary pump, modified to use a 28 VDC motor. The flow was controlled at $4.8 \mathrm{~L} \mathrm{~min}^{-1}$ by a flow meter and solenoid operated needle valve. After passing the flow controller the air either flowed directly into the instrument to measure NO, or was passed through a ferrous sulphate converter for $\mathrm{NO}_{x}^{\prime}$ measurements. The converter was completely isolated in the NO measurement mode. The air passed through a purge volume, the reaction vessel, and an ozone destroying catalyst to the pump which was exhausted outside the airplane. Ozone was produced from oxygen by an ozonator running at $8 \mathrm{kV} / 400$ $\mathrm{Hz}$ from a 28 VDC supply. In the measure mode, ozone was added at the reaction vessel and the resulting chemiluminescence detected by a thermoelectrically cooled photomultiplier tube (RCA C31034). For background, or zero 


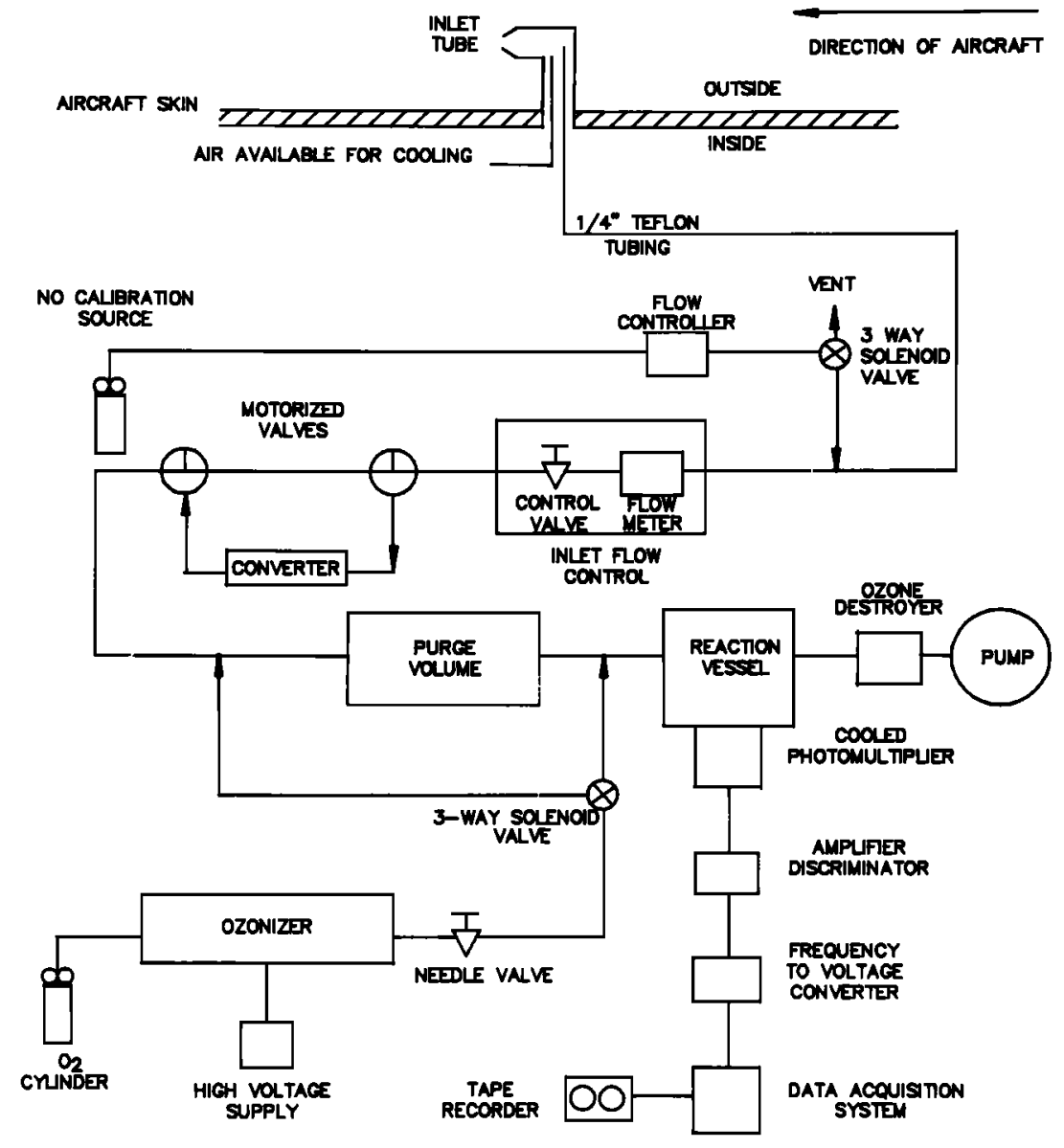

Fig. 1. Schematic of the $\mathrm{NO} / \mathrm{NO}_{x}^{\prime}$ instrument.

values, the ozone was added upstream of the purge volume. In this case the ozone reacted with the nitric oxide and the resulting $\mathrm{NO}_{2}$ was quenched to its ground state before entering the reaction vessel. The signal thus observed was then a combination of the photomultiplier tube (PMT) dark current and the chemiluminescence originating from ozone decomposition. To calibrate in flight, a known flow from a calibrated part per million level mixture of $\mathrm{NO}$ in $\mathrm{N}_{2}$ was added to the airstream at the entrance to the instrument.

The signal from the PMT was treated in a photon counting mode by an amplifier discriminator, to yield a stream of pulses. This pulse stream was fed to a frequency to voltage converter to produce an analog voltage suitable for recording. The output from the converter was averaged for $1 \mathrm{~min}$ by a Campbell Scientific Model 21X Datalogger and recorded, along with housekeeping information, on magnetic tape. The instrument was sequenced through zero, $\mathrm{NO}, \mathrm{NO}_{x}^{\prime}$ and calibration cycles by the operator on the aircraft. After each flight the tapes from the datalogger were returned to the laboratory where the data were read into a computer and final analysis performed.
Some recent versions of this type of instrumentation have included the addition of water to overcome humidity dependent sensitivity changes, and to lower the artifact signal [e.g., Carroll et al., 1985 ]. This was not done in this instrument as the majority of the missions were conducted in dry air and the sensitivity was not sufficiently high to be affected by an artifact signal.

Ferrous sulphate has been shown to be a nonspecific $\mathrm{NO}_{2}$ converter, capable of converting peroxyacetyl nitrate (PAN) and possibly other nitrates to NO [Fehsenfeld et al., 1987]. Thus the instrument as configured for this mission did not measure true $\mathrm{NO}_{x}\left(\mathrm{NO}+\mathrm{NO}_{2}\right)$, but rather $\mathrm{NO}_{x}^{\prime}\left(\mathrm{NO}_{x}+\mathbf{a}\right.$ fraction of organic nitrates). Conversion efficiencies for $\mathrm{NO}_{2}$, measured in the laboratory, exceeded $95 \%$ for the humidity range encountered in flight. $\mathrm{NO}_{x}^{\prime}$ values reported here assume $100 \%$ conversion efficiencies for all species detected.

The detection limit of the NO detector, defined as the square root of the zero counts divided by the instrument sensitivity, was $80 \mathrm{pptv}$ for a 1-s averaging time in the laboratory but degraded to $140 \mathrm{pptv}$ on the aircraft. Additional averaging by the datalogger to yield 1-min averages 
lowered the functional detection limit to $20 \mathrm{pptv}$. The precision of the measurements was $10 \%$ for mixing ratios greater than $50 \mathrm{pptv}$, and the accuracy, governed largely by the uncertainty in the calibration gas concentration, was $30 \%$. If the conversion efficiency is $100 \%$ for all species detected, the same detection limits, precision, and accuracy apply to $\mathrm{NO}_{x}^{\prime}$. For lower, unknown, conversion efficiencies, such as for organic nitrates, these parameters are not defined.

Details of the logistics of the measurement program are given in Galloway and Whelpdale [this issue]. The King Air performed a total of 30 research flights during WATOX-86. To characterize air masses leaving North America, 21 flights, nine during January and 12 during February, were performed some $50 \mathrm{~km}$ off the east coast with the operation based near Boston. A further nine flights were conducted around Bermuda in June to characterize mid-ocean air masses. NO and $\mathrm{NO}_{x}^{\prime}$ data are available for eight flights in January and 10 flights in February. Data from one flight were lost due to corruption of the data tape. The NO/NO $\mathrm{N}_{x}^{\prime}$ instrument failed catastrophically after a calibration flight out of Bermuda and could not be repaired in time to make a significant contribution to the measurement program; thus no $\mathrm{NO}_{x}^{\prime}$ data are available for Bermuda.

The sensitivity of the instrument is altitude independent but measurements could not be taken on ascent or descent as the rate of pressure change was too fast for the servo systems within the instrument. Consequently true altitude profiles above a single point could not be obtained. Measurements were taken on constant altitude legs. Normally at the beginning of each leg the instrument was zeroed and calibrated. For the remainder of the leg, measurements of $\mathrm{NO}$ or $\mathrm{NO}_{x}^{\prime}$ were taken under the control of the operator.

\section{RESULTS AND DISCUSSION}

\section{Data and Comparison With Other Measurements}

Table 1 gives the average $\mathrm{NO}$ and $\mathrm{NO}_{x}^{\prime}$ mixing ratios for each constant altitude flight leg off the east coast. Also listed are the standard deviation of this average and the number of 1 -min average measurements used in its determination. The standard deviation is a measure of the odd nitrogen variability, as in all cases it exceeds the measurement precision (the precision improves with the number of data points averaged). Isobaric and isentropic (where available) back trajectories have been used to identify the source region for each air mass sampled. Four sectors are defined in Figure 2 and the last column in Table 1 identifies the sector from which the air mass originated. In all cases the air originated over the continent and no marine air was sampled. These average mixing ratios are plotted as functions of altitude in Figures 3 and 4 . The boundary layer was determined for each flight and was usually about $1,000 \mathrm{~m}$. There are few data at this altitude as the aircraft avoided the cloud usually present at the top of the marine boundary layer.

For most of the data there is a clear difference between the boundary layer mixing ratios and those in the free troposphere. However, four $\mathrm{NO}_{x}^{\prime}$ and two NO mixing ratios in the free troposphere are anomalously high compared to other values, appearing to better reflect typical boundary layer mixing ratios. Examination of the flight logs show that, when these measurements were made, there was observable haze or cloud which was not present for the rest of the flights. Measurements in cloud could affect the converter performance but cannot explain why the data are a factor of 4 above other measurements at the same altitude, nor can they be responsible for the increases in NO observed. We must conclude that the $\mathrm{NO}_{x}^{\prime}$ is high due to physical lifting of boundary layer air into the free troposphere. On two of the days the log entries are consistent with strong vertical motion but not for the others. In these cases the air must have been displaced vertically prior to transport over the ocean.

Table 2 gives the free troposphere and boundary layer average mixing ratios determined from all the 1-min data points. Included for comparison are remote marine [Hoell et al., 1987; Davis et al., 1987; Ridley et al., 1987; Carroll and Ridley, 1984], remote continental [Fahey et al., 1986; Bollinger et al., 1984; Fehsenfeld et al., 1983; Parrish et al., 1986; Kley et al., 1981] and other western Atlantic Ocean [Luke and Dickerson, this issue] measurements. The free troposphere averages with and without the "anomalous" points, i.e., those high values identified above, are included. This division by altitude is different from that used by Whelpdale et al. [1984] and Galloway et al. [1984]. For the air mass flux calculations Whelpdale et al. [1984] took the region 0 to $1,500 \mathrm{~m}$ as being typical of the boundary layer. For the present data the top of the boundary layer was identified to occur at around $1,000 \mathrm{~m}$. In this data set there are insufficient measurements above $3,000 \mathrm{~m}$ to warrant separating the free tropospheric data into lower and middle free troposphere. Also included in the table are the standard deviations of the means, the number of data points used to obtain the average, and the maximum and minimum 1-min average mixing ratios.

The mixing ratios reported here are greater than those found in more remote environments. The average mixing ratios of NO in the boundary layer and free troposphere were 0.56 and $0.24 \mathrm{ppbv}$ respectively compared to the 0.001 and $0.1 \mathrm{ppbv}$ maxima reported by Hoell et al. [1987], Davis et al. [1987] and Ridley et al. [1987] off the west coast. Similarly the average mixing ratio of $\mathrm{NO}_{x}^{\prime}$ in the free troposphere was $0.55 \mathrm{ppbv}$, some 5 times the clear weather west coast $\mathrm{NO}_{x}$ value reported by Carroll and Ridley [1984]. These mixing ratios are also higher than those found in the more remote continental areas of Wyoming and Colorado. The boundary layer $\mathrm{NO}_{x}^{\prime}$ mixing ratio is 6 times the $\mathrm{NO}_{x}, 4$ times $\mathrm{NO}_{x}+\mathrm{PAN}$, and 3 times the total odd nitrogen, $\mathrm{NO}_{y}$, observed for clean air at Niwot Ridge. It is also 8 times the average continental boundary layer $\mathrm{NO}_{x}$ in Wyoming from Kley et al. [1981]. The free troposphere $\mathrm{NO}_{x}^{\prime}$ mixing ratio is 5 times the $\mathrm{NO}_{x}$ mixing ratio of 100 pptv reported by Kley et al. [1981] for Wyoming.

The measurements of Luke and Dickerson [this issue] should be directly comparable to those reported here as they were made from the NOAA P-3 aircraft, using similar instrumentation, in the first few days of the King Air measurement period. However, they show somewhat lower mixing ratios. Their median $\mathrm{NO}_{x}^{\prime}$ boundary layer mixing 


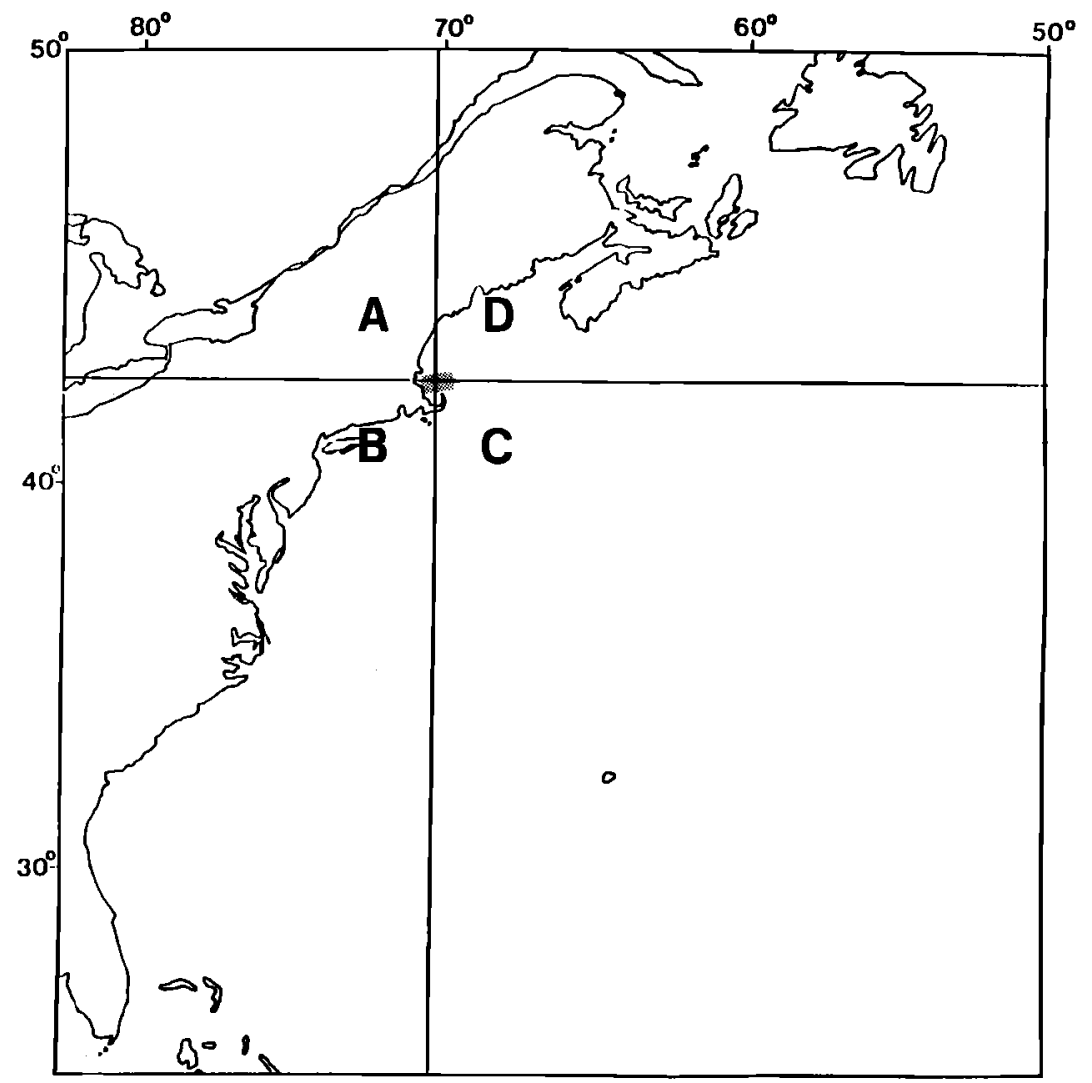

Fig. 2. Map showing the area over which the measurements were taken (shaded), and the sectors used for the trajectory classification.

ratios for the three flights were $0.17,1.51$ and $1.66 \mathrm{ppbv}$ compared to the average value of $2.92 \mathrm{ppbv}$ given in Table 2. Similarly they report $0.2 \mathrm{ppbv} \mathrm{NO}_{x}$ in the free troposphere compared to this average of $0.55 \mathrm{ppbv}$. These differences are within one standard deviation of the mean but are significant due to the large number of measurements.

The King Air performed its measurements within 50 $\mathrm{km}$ of the east coast whereas the P-3 was $250 \mathrm{~km}$ further east. Hastie et al. [1987] estimated that, in the western Atlantic boundary layer, $\mathrm{NO}_{x}^{\prime}$ decreases with a characteristic decay distance of $500 \mathrm{~km}$. This would suggest that the $\mathrm{NO}_{x}^{\prime}$ should decrease to $60 \%$ of its mixing ratio between platforms. This accounts for the bulk of the difference between the measurements. It does, however, bring into question whether flux determinations this far off shore are representative of the flux of material advected off the east coast.

\section{Frequency Distribution of $N O_{x}^{\prime}$ Measurements}

Figure 5 shows the NO and $\mathrm{NO}_{x}^{\prime}$ measurements on a boundary layer flight on February 8, 1986. It appears that there is a base mixing ratio of about $1 \mathrm{ppbv}$ with frequent sharp excursions to $10 \mathrm{ppbv}$. These excursions are of the order of 1 to $5 \mathrm{~min}$ in duration and result from the aircraft passing through plumes of pollutants which, as they are only 3 to $16 \mathrm{~km}$ across, must come from relatively close sources. This type of observation is difficult to parameterize for inclusion into flux calculations. Normally a mean and standard deviation are the only quoted parameters, but these tell nothing about the mixing ratio distribution function. Since we have 361 1-min averages, we have chosen to try to better describe the distribution of mixing ratios rather than rely solely on the mean and standard deviation.

Figure 6 shows the frequency distribution for the boundary layer $\mathrm{NO}_{x}^{\prime}$ measurements in 0.5 -ppbv intervals. The distribution is skewed to high mixing ratios with the mode in the $0.5-1 \mathrm{ppbv}$ interval but with 268 of the 361 data points at higher mixing ratios than this mode and fully half the points above $2.5 \mathrm{ppbv}$. The mean and standard deviation for this distribution are 2.9 and 2.4 respectively but clearly a normal distribution does not describe the distribution satisfactorily. The preferred function to describe a positively skewed distribution is the gamma probability distribution [e.g., Mendenhall and Scheaffer, 1973]:

$$
\begin{aligned}
f(y) & =\frac{y^{\alpha-1} \exp \frac{-y}{\beta}}{\beta^{\alpha} \Gamma(\alpha)} \alpha, \beta>0 ; 0 \leq y \leq \infty \\
f(y) & =0 \text { elsewhere }
\end{aligned}
$$


TABLE 1. NO and $\mathrm{NO}_{x}^{\prime}$ Concentrations From WATOX-86

\begin{tabular}{|c|c|c|c|c|c|c|c|c|}
\hline \multirow[b]{2}{*}{$\begin{array}{l}\text { Altitude } \\
\quad \mathbf{m}\end{array}$} & \multicolumn{3}{|c|}{ NO } & \multicolumn{3}{|c|}{$\mathrm{NO}_{x}^{\prime}$} & \multirow[b]{2}{*}{$\begin{array}{c}\text { Pressure } \\
\text { mbar }\end{array}$} & \multirow[b]{2}{*}{ Sector } \\
\hline & $\begin{array}{c}\text { Average } \\
\text { ppbv }\end{array}$ & $\begin{array}{l}\text { Standard } \\
\text { Deviation }\end{array}$ & Points & $\begin{array}{c}\text { Average } \\
\text { ppbv }\end{array}$ & $\begin{array}{l}\text { Standard } \\
\text { Deviation }\end{array}$ & Points & & \\
\hline \multicolumn{9}{|c|}{ January 4, 1986, a.m. } \\
\hline 253 & 0.30 & 0.07 & 9 & 2.24 & 0.55 & 5 & 983 & A-B \\
\hline 1207 & 0.38 & 0.05 & 23 & 1.16 & 0.09 & 9 & 876 & A-B \\
\hline 2420 & 0.32 & 0.03 & 11 & 0.75 & 0.09 & 24 & 754 & A-B \\
\hline 1966 & 0.33 & 0.03 & 14 & - & - & 0 & 798 & A-B \\
\hline 729 & 0.30 & 0.02 & 3 & - & - & 0 & 929 & A-B \\
\hline \multicolumn{9}{|c|}{ January 4, 1986, p.m. } \\
\hline 1661 & 0.13 & 0.01 & 4 & 0.49 & 0.06 & 7 & 829 & A-B \\
\hline 2882 & 0.12 & 0.01 & 3 & 0.35 & 0.03 & 10 & 712 & A-B \\
\hline \multicolumn{9}{|c|}{ January 6, 1986, a.m. } \\
\hline 367 & 0.70 & 0.39 & 42 & 6.32 & 1.42 & 9 & 970 & A \\
\hline 1793 & 1.55 & 0.12 & 11 & 3.45 & 0.30 & 15 & 816 & A \\
\hline 3299 & 0.40 & 0.02 & 2 & 1.25 & 0.42 & 21 & 675 & $A$ \\
\hline \multicolumn{9}{|c|}{ January 7, 1986, p.m. } \\
\hline 259 & 0.16 & 0.11 & 17 & 3.91 & 0.95 & 5 & 982 & A \\
\hline 716 & 1.60 & 0.15 & 8 & 5.10 & 0.57 & 3 & 930 & $\mathrm{~A}$ \\
\hline 1687 & 0.08 & 0.02 & 8 & 1.02 & 0.25 & 17 & 826 & $\mathrm{~A}$ \\
\hline 2886 & 0.19 & 0.11 & 19 & 3.76 & 0.27 & 3 & 711 & $A$ \\
\hline 2575 & 0.13 & 0.01 & 8 & - & - & 0 & 740 & $A$ \\
\hline \multicolumn{9}{|c|}{ January 8,1986, a.m. } \\
\hline 3119 & 0.14 & 0.02 & 15 & 0.66 & 0.04 & 15 & 690 & $A$ \\
\hline 1452 & 0.03 & 0.02 & 20 & 0.27 & 0.01 & 2 & 850 & $\mathrm{~A}$ \\
\hline 419 & 0.37 & 0.15 & 10 & 1.56 & 0.54 & 14 & 964 & $A$ \\
\hline \multicolumn{9}{|c|}{ January 8,1986, p.m. } \\
\hline 2340 & 0.32 & 0.02 & 5 & - & - & 0 & 762 & A \\
\hline 1738 & 0.26 & 0.01 & 3 & - & - & 0 & 821 & $A$ \\
\hline 1140 & 0.05 & 0.02 & 8 & - & - & 0 & 884 & $\mathrm{~A}$ \\
\hline 622 & 0.13 & 0.02 & 12 & 1.50 & 0.22 & 6 & 941 & $A$ \\
\hline \multicolumn{9}{|c|}{ January 9, 1986, a.m. } \\
\hline 3166 & - & - & 0 & - & - & 0 & 686 & A \\
\hline 203 & 2.28 & 0.44 & 15 & - & - & 0 & 989 & A \\
\hline 883 & 0.14 & 0.04 & 14 & 0.43 & 0.06 & 13 & 912 & $A-B$ \\
\hline \multicolumn{9}{|c|}{ January 9,1986, p.m. } \\
\hline 2243 & 0.12 & 0.03 & 23 & 0.31 & 0.07 & 13 & 771 & A \\
\hline 1964 & 0.12 & 0.02 & 27 & - & - & 0 & 799 & $\mathrm{~A}$ \\
\hline 240 & 0.18 & 0.03 & 14 & 0.75 & 0.04 & 5 & 985 & A-B \\
\hline 926 & 0.18 & 0.02 & 11 & 0.58 & 0.03 & 12 & 907 & A-B \\
\hline \multicolumn{9}{|c|}{ February 6, 1986, p.m. } \\
\hline 186 & 0.17 & 0.04 & 19 & 0.84 & 0.10 & 3 & 991 & $\mathrm{~A}$ \\
\hline 1777 & 0.18 & 0.04 & 25 & 0.52 & 0.02 & 7 & 817 & $\mathrm{~A}$ \\
\hline 2687 & 0.17 & 0.04 & 20 & 0.49 & 0.02 & 4 & 729 & $\mathrm{~A}$ \\
\hline 714 & 0.13 & 0.04 & 19 & 0.95 & 0.07 & 5 & 930 & A \\
\hline \multicolumn{9}{|c|}{ February 8,1986, p.m. } \\
\hline 134 & 0.34 & 0.22 & 14 & 1.35 & 0.65 & 20 & 997 & B \\
\hline 465 & 0.82 & 0.39 & 11 & 3.78 & 1.64 & 24 & 959 & $\mathrm{~B}$ \\
\hline
\end{tabular}


TABLE 1. (continued)

\begin{tabular}{|c|c|c|c|c|c|c|c|c|}
\hline \multirow[b]{2}{*}{$\begin{array}{l}\text { Altitude } \\
\text { m }\end{array}$} & \multicolumn{3}{|c|}{ No } & \multicolumn{3}{|c|}{$\mathrm{NO}_{x}^{\prime}$} & \multirow[b]{2}{*}{$\begin{array}{c}\text { Pressure } \\
\text { mbar }\end{array}$} & \multirow[b]{2}{*}{ Sector } \\
\hline & $\begin{array}{c}\text { Average } \\
\text { ppbv }\end{array}$ & $\begin{array}{l}\text { Standard } \\
\text { Deviation }\end{array}$ & Points & $\begin{array}{c}\text { Average } \\
\text { ppbv }\end{array}$ & $\begin{array}{l}\text { Standard } \\
\text { Deviation }\end{array}$ & Points & & \\
\hline 3063 & 0.19 & 0.05 & 6 & 0.93 & 0.06 & 23 & 695 & $\mathrm{~B}$ \\
\hline 4302 & 0.31 & 0.18 & 10 & 2.65 & 0.80 & 17 & 592 & B \\
\hline \multicolumn{9}{|c|}{ February 9,1986, a.m. } \\
\hline 134 & 0.12 & 0.03 & 9 & 1.37 & 0.87 & 13 & 997 & $A-B$ \\
\hline 558 & 0.24 & 0.01 & 3 & 1.29 & 1.09 & 35 & 948 & A-B \\
\hline \multicolumn{9}{|c|}{ February $9,1986, p . m$} \\
\hline 2734 & 1.16 & 0.28 & 6 & 4.17 & 0.69 & 10 & 725 & A-B \\
\hline 3648 & 0.13 & 0.05 & 12 & 0.58 & 0.05 & 27 & 645 & A-B \\
\hline 2437 & - & - & 0 & - & - & 0 & 753 & $A-B$ \\
\hline 1230 & 0.38 & - & 1 & - & - & 0 & 874 & $A-B$ \\
\hline 628 & - & - & 0 & 1.53 & 0.20 & 3 & 940 & $A-B$ \\
\hline \multicolumn{9}{|c|}{ February 10, 1986, p.m. } \\
\hline 263 & 0.03 & - & 1 & - & - & 0 & 982 & $\mathbf{B}$ \\
\hline 263 & 1.06 & 0.06 & 3 & 4.23 & 1.61 & 20 & 982 & $\mathbf{B}$ \\
\hline 634 & 0.37 & 0.10 & 6 & 5.89 & 2.66 & 23 & 939 & $\mathbf{B}$ \\
\hline 1687 & 0.41 & 0.15 & 20 & 1.25 & 0.19 & 3 & 826 & B \\
\hline 2748 & 0.05 & 0.01 & 9 & 0.36 & 0.08 & 22 & 724 & $\mathrm{~B}$ \\
\hline \multicolumn{9}{|c|}{ February 12, 1986, p.m. } \\
\hline 316 & - & - & 0 & - & - & 0 & 976 & $A-B$ \\
\hline 675 & 0.29 & 0.17 & 18 & 1.51 & 0.72 & 11 & 935 & A-B \\
\hline 1885 & 0.08 & 0.01 & 5 & 0.35 & 0.08 & 23 & 806 & $A-B$ \\
\hline 2489 & 0.04 & 0.01 & 5 & 0.29 & 0.08 & 31 & 748 & $A-B$ \\
\hline \multicolumn{9}{|c|}{ Febmuary 13, 1986, a.m. } \\
\hline 167 & 0.12 & 0.05 & 13 & - & - & 0 & 993 & A-B \\
\hline 489 & 0.20 & 0.07 & 7 & 1.03 & 0.14 & 20 & 956 & A-B \\
\hline 1705 & 0.04 & 0.02 & 8 & 0.27 & 0.05 & 12 & 824 & $A-B$ \\
\hline 2754 & 0.08 & 0.03 & 14 & 0.23 & 0.05 & 4 & 723 & $A-B$ \\
\hline \multicolumn{9}{|c|}{ February 13, 1986, p.m. } \\
\hline 284 & 1.77 & 0.40 & 18 & 6.69 & 1.87 & 22 & 980 & A-B \\
\hline 578 & 1.03 & 0.16 & 7 & 6.94 & 1.31 & 18 & 946 & A-B \\
\hline 1846 & 0.13 & 0.01 & 3 & 0.27 & 0.02 & 14 & 810 & $A-B$ \\
\hline 2753 & 0.13 & - & 1 & 0.26 & 0.04 & 28 & 723 & $A-B$ \\
\hline \multicolumn{9}{|c|}{ February 15,1986, p.m. } \\
\hline 271 & 0.56 & 0.06 & 8 & 2.79 & 0.25 & 17 & 981 & $\mathrm{~B}$ \\
\hline 868 & 1.05 & 0.15 & 10 & 3.72 & 1.12 & 28 & 913 & $\mathrm{~B}$ \\
\hline 1922 & 0.15 & - & 1 & 0.95 & 0.09 & 30 & 803 & $\mathrm{~B}$ \\
\hline 2825 & 0.07 & 0.02 & 6 & 0.23 & 0.07 & 17 & 717 & $\mathrm{~B}$ \\
\hline \multicolumn{9}{|c|}{ February 16,1986, p.m. } \\
\hline 124 & 0.70 & 0.15 & 18 & 2.10 & 0.04 & 2 & 999 & A \\
\hline 716 & 0.14 & 0.04 & 14 & 0.93 & 0.30 & 25 & 930 & A \\
\hline 2424 & 0.10 & 0.01 & 6 & 0.30 & 0.03 & 22 & 754 & A \\
\hline 3025 & 0.11 & 0.01 & 11 & 0.28 & 0.07 & 20 & 699 & $A$ \\
\hline
\end{tabular}

A total of 721 data points were used for NO, 811 for $\mathrm{NO}_{x}^{\prime}$. 


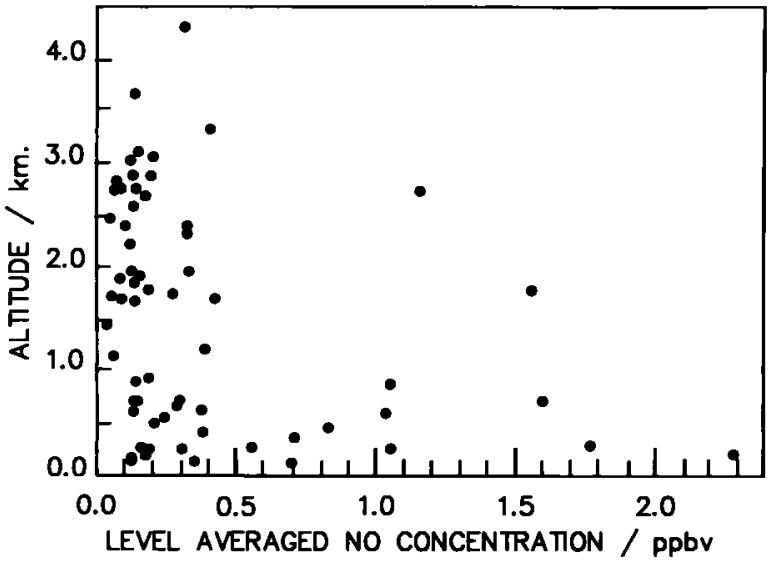

Fig. 3. NO mixing ratios as a function of altitude. Each point is the average of a constant altitude flight leg.

where $\Gamma(\alpha)$ is the gamma function.

For an $\alpha$ of 1 the distribution collapses to an exponential decay. As $\alpha$ increases the distribution becomes less skewed until for $\alpha=4$ it becomes symmetrical. The data were fitted to a gamma distribution function in two ways, both using $\alpha$ and $\beta$ as fitting parameters. The first, an iterative procedure, varied $\alpha$ and $\beta$ to minimize the difference between the gamma distribution and the data. In the second method the fact that the mean and standard deviation of a gamma distribution are given by $\alpha \beta$ and $\alpha \beta^{2}$, respectively, was used to generate $\alpha$ and $\beta$ directly from calculated mean and standard deviations. Due to the complexity of the first method only the boundary layer $\mathrm{NO}_{x}^{\prime}$ was treated by both analyses. Figure 7 shows the resulting gamma distribution for the boundary layer $\mathrm{NO}_{x}$ for which the second method gives $\alpha$ and $\beta$ values of 1.44 and 2.02 respectively. The normal distribution generated from the mean and standard deviation of the data and the data

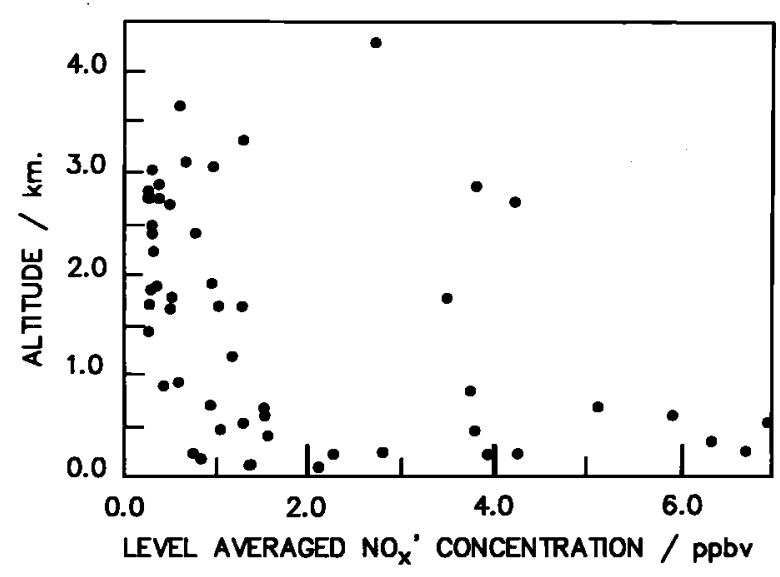

Fig. 4. $\mathrm{NO}_{x}^{\prime}$ mixing ratios as a function of altitude. Each point is the average of a constant altitude flight leg.

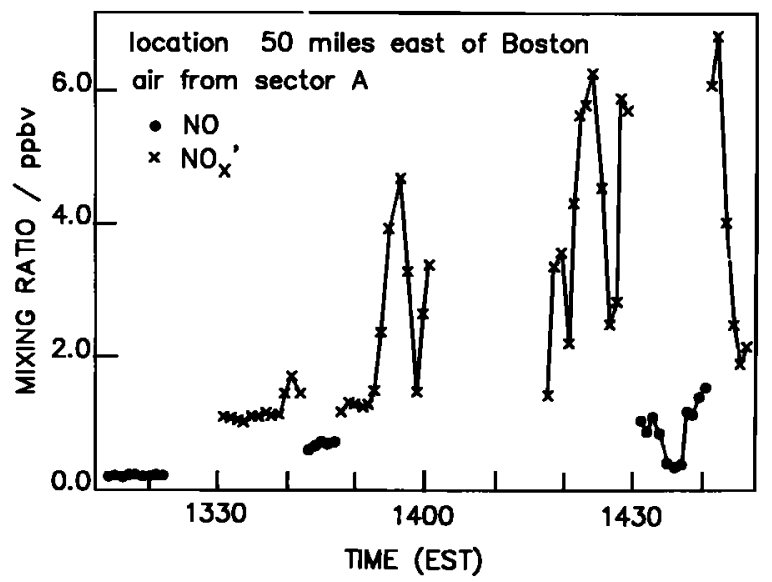

Fig. 5. $\mathrm{NO}$ (solid circles) and $\mathrm{NO}_{x}^{\prime}$ (crosses) mixing ratios as measured in the boundary layer on February 8, 1986.

itself are also plotted. Clearly the gamma distribution provides a better fit to the data than the normal distribution. The free troposphere $\mathrm{NO}_{x}^{\prime}$ distribution, in 0.25 -ppbv intervals, is shown in Figure 8 and while still skewed, appears closer to being normal. A gamma distribution was fitted to these data and yielded $\alpha$ and $\beta$ values of 2.47 and 0.22 respectively. The higher value of $\alpha$ shows the distribution is much more symmetric about the mean than is the boundary layer distribution.

The same analysis was performed on the NO data and the results of all the $\alpha$ and $\beta$ determinations are summarized in Table 3 .

\section{Other Observations}

The high $\mathrm{NO}$ and $\mathrm{NO}_{x}^{\prime}$ mixing ratios measured here show that both boundary layer and free tropospheric air at least $50 \mathrm{~km}$ over the western Atlantic Ocean are rich in

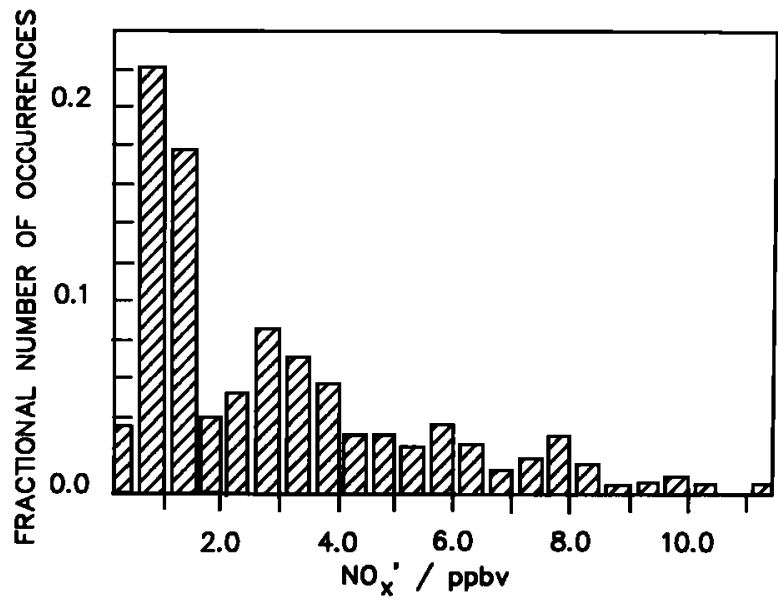

Fig. 6. Boundary layer $\mathrm{NO}_{x}^{\prime}$ frequency distribution in $\mathbf{0 . 5 -}$ ppbv intervals. 
TABLE 2. Average NO and $\mathrm{NO}_{x}^{\prime}$ Concentrations in Boundary Layer and Free Troposphere

\begin{tabular}{|c|c|c|c|c|c|c|c|}
\hline & \multicolumn{4}{|c|}{ This Work } & \multirow[b]{2}{*}{$\begin{array}{l}\text { Atlantic } \\
\text { Marine }\end{array}$} & \multirow[b]{2}{*}{$\begin{array}{l}\text { Pacific } \\
\text { Marine }\end{array}$} & \multirow[b]{2}{*}{$\begin{array}{l}\text { Remote }^{d} \\
\text { Continental }\end{array}$} \\
\hline & Mean & $\begin{array}{l}\text { Standard } \\
\text { Deviation }\end{array}$ & Points $^{a}$ & Range & & & \\
\hline \multicolumn{8}{|c|}{ Boundary Layer } \\
\hline NO & 0.56 & 0.61 & 353 & $0.02-2.59$ & & 0.001 & \\
\hline $\mathrm{NO}_{x}^{\prime}$ & 2.92 & 2.43 & 361 & $0.32-11.2$ & 1.24 & $\leq 0.1$ & $\leq 0.5$ \\
\hline \multicolumn{8}{|c|}{ Free Troposphere (excluding anomalies) } \\
\hline NO & 0.18 & 0.13 & 351 & $0.02-0.83$ & & $\leq 0.01$ & \\
\hline $\mathrm{NO}_{x}^{\prime}$ & 0.55 & 0.35 & 405 & $0.14-2.34$ & 0.24 & $\leq 0.1$ & $\leq 0.2$ \\
\hline \multicolumn{8}{|c|}{ Free Troposphere (including anomalies) } \\
\hline NO & 0.24 & 0.29 & 368 & $0.02-1.71$ & & & \\
\hline $\mathrm{NO}_{x}^{\prime}$ & 0.83 & 0.94 & 450 & $0.14-4.94$ & & & \\
\hline
\end{tabular}

All concentrations are in parts per billion by volume.

a The number of 1-min data points used to generate the average.

${ }^{b}$ Luke and Dickerson [this issue], obtained by averaging the median values for each flight.

${ }^{\epsilon}$ Hoell et al. [1987], Davis et al. [1987] and Ridley et al. [1987]

${ }^{d}$ Kley et al. [1981]

odd nitrogen compounds compared to remote continental and marine environments. These compounds must have a different source from those observed over the Pacific Ocean since the odd nitrogen mixing ratio over the Pacific Ocean increases in going from the boundary layer to the free troposphere whereas the reverse behavior was observed over the Atlantic Ocean.

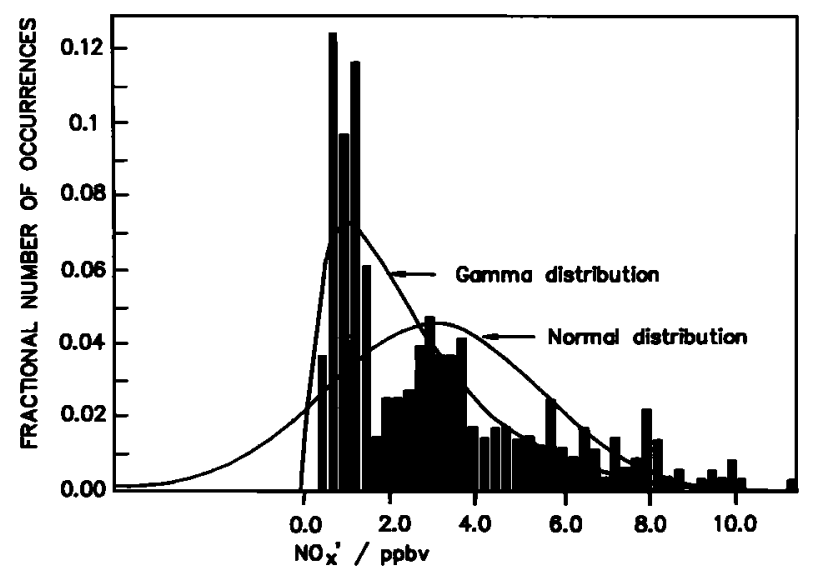

Fig. 7. Boundary layer $\mathrm{NO}_{x}^{\prime}$ frequency distribution in 0.25 -ppbv intervals with the best fit normal and gamma distributions superimposed.
There is substantial evidence that, in this region, the elevated mixing ratios arise from inputs within the boundary layer. Figure 9 compares the $\mathrm{NO}_{x}^{\prime}$ mixing ratio distributions for the free troposphere and the boundary layer for mixing ratios less than 5 ppbv. The average mixing ratio in the boundary layer exceeds the free troposphere value (Table 2) but the figure shows this is not only due

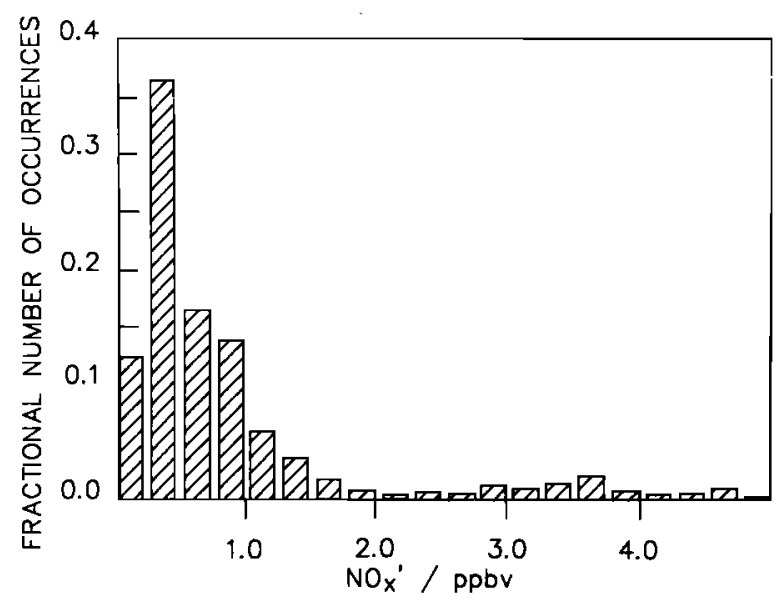

Fig. 8. Free troposphere $\mathrm{NO}_{x}^{\prime}$ frequency distribution in $0.25-\mathrm{ppbv}$ intervals. 
TABLE 3. Values of $\alpha$ and $\beta$ From Fit of Data to Gamma Function

\begin{tabular}{cccccc}
\hline & & & \multicolumn{2}{c}{ NO } \\
\cline { 2 - 3 } $\begin{array}{c}\text { Free } \\
\text { Tropo- } \\
\text { sphere }\end{array}$ & $\begin{array}{c}\mathrm{NO}_{x}^{\prime} \\
\text { Boundary } \\
\text { Layer }\end{array}$ & $\begin{array}{c}\text { Free } \\
\text { Tropo- } \\
\text { sphere }\end{array}$ & $\begin{array}{c}\text { Boundary } \\
\text { Layer }\end{array}$ \\
\hline$\alpha$ & 2.47 & $1.44(1.56)^{*}$ & 1.92 & 0.84 \\
$\beta$ & 0.22 & $2.02(1.60)^{*}$ & 0.094 & 0.66
\end{tabular}

"Values calculated by the iterative procedure, see text.

to the excursions to high concentrations, but also to the higher base mixing ratio in the boundary layer. This shows that the transport of odd nitrogen in this area is from the boundary layer into the free troposphere. Since the free tropospheric mixing ratios are also elevated compared to the remote values, the lifetime of $\mathrm{NO}_{x}^{\prime}$ in the boundary layer must be greater than the time for transport to the free troposphere. The variability in the boundary layer mixing ratios is higher than for the free troposphere which indicates that the odd nitrogen compounds are not as well dispersed in the boundary layer consistent with a boundary layer odd nitrogen source.

The high mixing ratios of $\mathrm{NO}_{x}^{\prime}$ above the background level as exemplified by Figure 5 are likely due to local sources close to the east coast. These excursions are from 3 to $16 \mathrm{~km}$ across. Assuming this material were due to a point source, a Gaussian dispersion model with horizontal dispersion coefficients for an atmosphere of average stability [Turner, 1970] suggests the source is between 20 and $100 \mathrm{~km}$ from the measurement point. As the aircraft was $50 \mathrm{~km}$ from the coast this is consistent with a near coastal source. Since care was taken to avoid the Boston plume, smaller emission centers are being detected.

The source of the base $\mathrm{NO}_{x}^{\prime}$ in the boundary layer must be within the boundary layer, but since its mixing ratio is twice that encountered in remote continental areas [Fahey et al., 1986; Bollinger et al., 1984; Fehsenfeld et al., 1983; Parrish et al., 1986] it is unlikely to be of natural origin. It therefore must originate from anthropogenic sources that are sufficiently distant from the measurement area to prevent distinguishing individual sources.

\section{CONCLUSIONS}

The mixing ratios of $\mathrm{NO}$ and $\mathrm{NO}_{x}^{\prime}$ off the east coast of North America are higher than those encountered in remote continental or marine environments. The odd nitrogen source has been shown to be within the boundary layer and is largely anthropogenic. Within the boundary layer, local sources are readily identified by plumes of high $\mathrm{NO}_{x}^{\prime}$ mixing ratios, but even the base level indicates anthropogenic sources that cannot be distinguished. The

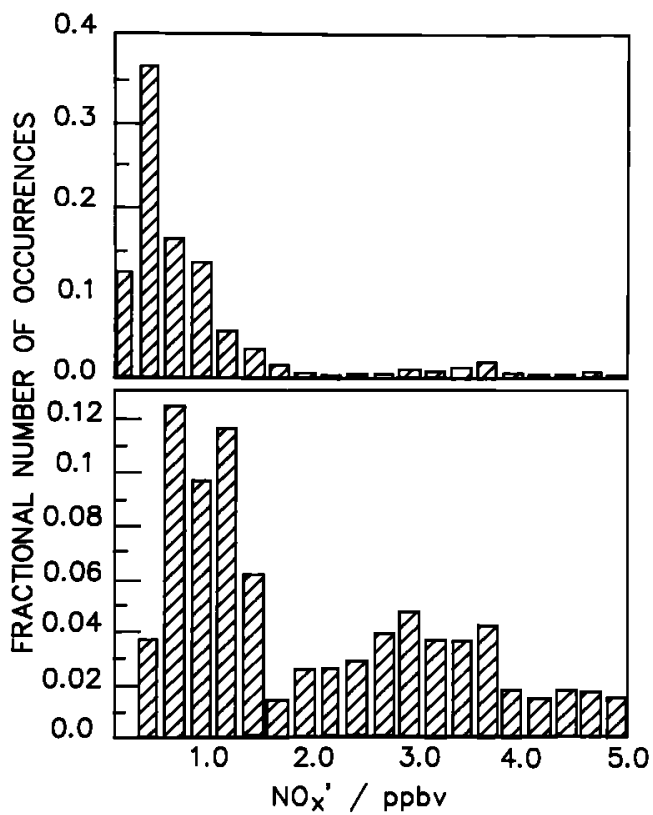

Fig. 9. Boundary layer $\mathrm{NO}_{x}^{\prime}$ frequency distribution for values less than 5 ppbv in 0.25 -ppbv intervals (lower) and free troposphere $\mathrm{NO}_{x}^{\prime}$ frequency distribution in $0.25-\mathrm{ppbv}$ intervals (upper).

mean mixing ratios observed were $2.9 \mathrm{ppbv}$ in the boundary layer and $0.55 \mathrm{ppbv}$ in the free troposphere for $\mathrm{NO}_{x}^{\prime}$, and $0.56 \mathrm{ppbv}$ in the boundary layer and 0.18 in the free troposphere for NO. The mean and standard deviation are not sufficient to describe the free troposphere or boundary layer mixing ratio distributions since the measurements are skewed toward high mixing ratios and are best described by a gamma probability distribution.

Acknowledgements. This work was supported by the Atmospheric Environment Service (AES) of Environment Canada, the National Sciences and Engineering Research Council and the Ontario Ministry of the Environment. B.A.M. wishes to thank AES for the educational leave under which this work was performed. The authors wish to thank those responsible for the WATOX program for the opportunity to participate, the NOAA aircraft group, particularly J. Boatman, L. Gunter, and D. Wellman for their assistance, R. Artz and J. Harris for the trajectories, and D. M. Whelpdale and J. N. Galloway for their continued support.

\section{REFERENCES}

Bollinger, M. J., C. J. Hahn, D. D. Parrish, P. C. Murphy, D. L. Albritton, and F. C. Fehsenfeld, $\mathrm{NO}_{x}$ measurements in clean continental air and analysis of the contributing meteorology. J. Geophys. Res., 89, 9623-9631, 1984.

Carroll, M. A., and B. A. Ridley, Tropospheric $\mathrm{NO}_{x}$ mea- 
surements, paper presented at AGU Fall Meeting, San Francisco, Calif., 1984.

Carroll, M. A., M. McFarland, B. A. Ridley, and D. L. Albritton, Ground-based nitric oxide measurements at Wallops Island, Virginia, J. Geophys. Res., 90, 12853$12860,1985$.

Davis, D. D., J. D. Bradshaw, M. O. Rogers, S. T. Sandholm, and S. KeShang, Free tropospheric and boundary layer measurements of NO over the central and eastern North Pacific Ocean, J. Geophys. Res., 92, 2049-2070, 1987.

Fahey, D. W., G. T. Hübler, D. D. Parrish, E. J. Williams, R. B. Norton, B. A. Ridley, H. B. Singh, S. C. Liu, and F. C. Fehsenfeld, Reactive nitrogen species in the troposphere: Measurements of $\mathrm{NO}, \mathrm{NO}_{2}, \mathrm{HNO}_{3}$, particulate nitrate, peroxyacetyl nitrate (PAN), $\mathrm{O}_{3}$, and total reactive odd nitrogen $\left(\mathrm{NO}_{y}\right)$ at Niwot Ridge, Colorado, $J$. Geophys. Res., 91, 9781-9793, 1986.

Fehsenfeld, F. C., M. J. Bollinger, S. C. Lui, D. D. Parrish, M. McFarland, M. Trainer, D. Kley, P. C. Murphy, and D. L. Albritton, A study of ozone in the Colorado Mountains, J. Atmos. Chem., 1, 87-105, 1983.

Fehsenfeld, F. C., et al., A ground-based intercomparison of $\mathrm{NO}, \mathrm{NO}_{x}$ and $\mathrm{NO}_{y}$ measurement techniques, J. Geophys. Res., 92, 14710-14722, 1987.

Galloway, J. N., and D. M. Whelpdale, WATOX-86 overview and western North Atlantic Ocean $\mathrm{S}$ and $\mathrm{N}$ atmospheric budgets, Global Biogeochem. Cycles, this issue.

Galloway, J. N., D. M. Whelpdale, and G. T. Wolf, The flux of $\mathrm{S}$ and $\mathrm{N}$ eastward from North America, Atmos. Environ., 18, 2595-2607, 1984.

Galloway, J. N., R. S. Artz, U. Dyan, and R. Pueschell, WATOX-85: An aircraft and ground sampling program to determine the transport of trace gases and aerosols across the western Atlantic Ocean, Atmos. Environ., in press, 1987.

Hastie, D. R., Q. Tran, H. I. Schiff, and G. W. Harris, Measurements of the nitrogen oxides in the Western Atlantic Ocean Experiment (WATOX), Paper presented at the AGU Fall Meeting, San Francisco, Calif., 1985.

Hastie, D. R., H. I. Schiff, D. M. Whelpdale, R. Peterson, W. Zoller, and D. Anderson, Nitrogen and sulphur over the Western Atlantic Ocean, Atmos. Environ., in press, 1988.

Hoell, J. M., Jr., G. L. Gregory, D. S. McDougal, A. L. Torres, D. D. Davis, J. Bradshaw, M. O. Rodgers, B. A. Ridley, and M. A. Carroll, Airborne intercomparison of nitric oxide measurement techniques, J. Geophys. Res., 92, 1995-2008, 1987.

Kley, D., J. W. Drummond, M. McFarland, and S. C. Liu, Tropospheric profiles of $\mathrm{NO}_{x}, J$. Geophys. Res., 86, 3153-3161, 1981.

Logan, J. A., Nitrogen oxides in the troposphere: Global and regional budgets, J. Geophys. Res., 88, 10,78510,807, 1983.

Luke, W. T., and R. R. Dickerson, The flux of reactive nitrogen compounds from eastern North America to the western Atlantic Ocean, Global Biogeochem. Cycles, this issue.

McFarland, M., D. Kley, J. W. Drummond, A. L. Schmeltekopf, and $\mathrm{R}$. H. Winkler, Nitric oxide measurements in the equatorial Pacific region, Geophys. Res. Lett., 6, 605-608, 1979.

Mendenhall, W., and R. L. Scheaffer, Mathematical Statistics and Applications, Duxbury Press, North Scituate, Mass., 1973.

Mueller, P. K., and G. M. Hidy, The Sulphate Regional Experiment: Report of findings, vol. 1 and 2, Rep. EA1901 Electr. Power Res. Inst., Palo Alto, California, 1983.

National Academy of Sciences (NAS), Global Tropospheric Chemistry: A Plan for Action, National Academy Press, Washington, D. C., 1984.

Parrish, D. D., R. B. Norton, M. J. Bollinger, S. C. Liu, P. C. Murphy, D. L. Albritton, F. C. Fehsenfeld, and B. J. Heubert, Measurements of $\mathrm{HNO}_{3}$ and $\mathrm{NO}_{3}^{-}$particulates at a rural site in the Colorado Mountains, J. Geophys. Res., 91, 5379-5393, 1986.

Ridley, B. A., M. A. Carroll, and G. L. Gregory, Measurements of nitric oxide in the boundary layer and free troposphere over the Pacific Ocean, J. Geophys. Res., 92, 2025-2047, 1987.

Torres, A. L., Nitric oxide measurements at a nonurban eastern United States site: Wallops instrument results from July 1983 GTE/CITE mission, J. Geophys. Res., 90, 12875-12880, 1985.

Turner, D. B., Workbook of atmospheric dispersion estimates, Publ. 999-AP-26, Public Health Serv., Washington D. C., 1970. (Available from Natl. Tech. Inf. Serv., Springfield, Va.)

Whelpdale, D. M., T. B. Low, and R. J. Kolomeychuk, Advection climatology for the east coast of North America Atmos. Environ. 18, 1311-1327, 1984.

Wolff, G. T., N. A. Kelley, M. A. Ferman, M. S. Ruthkosky, D. P. Stroup, and P. E. Korsog, Measurements of sulphur dioxides, nitrogen oxides, haze and fine particles at a rural site on the Atlantic coast, J. Air Pollut. Control Assoc., 36, 585-591, 1986a.

Wolff, G. T., M. S. Ruthkosky, D. P. Stroup, P. E. Korsog, M. A. Ferman, G. J. Wendel, and D. H. Stedman, Measurements of $\mathrm{SO}_{x}, \mathrm{NO}_{x}$ and aerosol species on Bermuda Atmos. Environ. 20, 1229-1239, 1986b.

D. R. Hastie, B. A. Misanchuk, and H. I. Schiff, Chemistry Department and Centre for Atmospheric Chemistry, York University, 4700 Keele Street, North York, Ontario, Canada M3J 1 P3.

(Received September 14, 1987; revised January 19, 1988; accepted January 26, 1988.) 